\title{
PENERAPAN METODE SIMPLEKS UNTUK OPTIMASI PRODUKSI IKAN AIR TAWAR DAN IKAN AIR PAYAU DI KABUPATEN CILACAP SERTA ANALISIS KELAYAKAN PRODUKSI SECARA SENSITIVITAS
}

\author{
Rostika Listyaningrum(1), Ika Nur Afiati ${ }^{2)}$ \\ ${ }^{1) 2)}$ Program Studi Teknik Informatika, Politeknik Negeri Cilacap \\ Jln. Dr Soetomo No 1, Sidakaya, Cilacap \\ nadhifa007@gmail.com
}

Kata Kunci:
metode simpleks,
analisis sensitivitas,
produktivitas ikan
air tawar dan air
payau

\begin{abstract}
Abstrak
Kabupaten Cilacap merupakan salah satu wilayah yang berpotensi maju dalam bidang pengolahan budidaya perairan.Potensi sumberdaya perikanan budidaya air tawar (kolam)dan air payau (tambak)sebarannya berada hampir diseluruh wilayah Kabupaten Cilacap dan masih sangat berpotensi untuk dikembangkan. Makalah ini membahas penerapan metode simpleks pada persoalan produktivitas budidaya ikan air tawar (kolam) dan ikan air payau (tambak) di Kabupaten Cilacap. Solusi optimal yang diperoleh dari metode simpleks diuji kelayakan perubahannya secara analisis sensitivitas.Produktivitasmaksimum ikan air tawar (kolam) dan ikan air payau (tambak) selama tahun 2014 - 2016 diperoleh sebanyak 28. 784,4494 ton.
\end{abstract}

\begin{tabular}{|c|c|}
\hline & Abstract \\
\hline $\begin{array}{l}\text { Keywords: } \\
\text { Simplex method, } \\
\text { sensitivity analysis, } \\
\text { productivity of fresh } \\
\text { water and brackish } \\
\text { water }\end{array}$ & $\begin{array}{l}\text { Cilacap Regency is one of region whose good potential in process of waterpark cultivation. The resource } \\
\text { potential of fresh water cultivation and brackish water and is distribution is almost in Cilacap } \\
\text { Regency, and it still has potential to develop. This research discussed the application of simplex method } \\
\text { on the productivity of fresh water cultivation and brackish water in Cilacap Regency. The optimal } \\
\text { solution from simplex method was tested its change of reliability with sensitivity analysis. The } \\
\text { maximum productivity of fresh water and brackish water in } 2014 \text { till } 2016 \text { was } 28.784,4494 \text { tons. }\end{array}$ \\
\hline
\end{tabular}

\footnotetext{
هlamat korespondensi :

E-mail : nadhifaoo7@gmail.com

ISSN : 2087-1627
} 


\section{PENDAHULUAN}

\subsection{Latar Belakang}

Kabupaten Cilacap merupakan salah satu wilayah yang berpotensi maju dalam bidang pengolahan budidaya perairan. Potensi usaha perikanan budidaya terbagi ke dalam budidaya air tawar, budidaya air payau, dan budidaya air laut. Potensi sumberdaya perikanan budidaya air tawar dan air payau sebarannya berada hampir diseluruh wilayah Kabupaten Cilacap dan masih sangat berpotensi untuk dikembangkan.

Berdasarkan data dari Badan Pusat Statistik Kabupaten Cilacap, luas budidaya ikan di air tawar (kolam) dan air payau (tambak) dari tahun ke tahun mengalami penurunan. Produktivitas ikan air tawar (kolam) dan ikan air payau (tambak) yang diperoleh dari tahun ke tahun juga tidak selalu sama. Hal inilah yang mendorong penulis untuk mengetahui produktivitas ikan di air tawar (kolam) dan air payau (tambak) yang optimal. Metode yang akan digunakan adalah menggunakan metode simpleks. Solusi optimal yang diperoleh dari metode simpleks dapat diuji kelayakan perubahannya secara analisis sensitivitas. Analisis sensitivitas merupakan suatu analisis terhadap perubahan pada interval hasil yang mungkin terjadi dari suatu persoalan pemrograman linier [6], sehingga hasil perhitungan produksi ikan di air tawar (kolam) dan air payau (tambak) optimum yang diperoleh pada penelitian ini menjadi lebih baik dan optimal.

Penelitian relevan telah dilakukan oleh Indrawati,dkk (2012) yang menganalisis produksi padi dengan metode simpleks dan analisis sensitivitas. Penelitian tersebut memperoleh hasil produksi padi maksimum dengan pembentukan fungsi tujuan menggunakan program linier dan diselesaikan menggunakan metode simpleks dan analisis sensitivitas. Elva, YA. (2015) meneliti penerapan metode hongaria dan metode simpleks dalam upaya optimasi. Pada penelitian tersebut diperoleh laba maksimum pada perusahaan konveksi dengan menggunakan metode simpleks. Zuhria N, dkk (2016) telah meneliti penerapan metode simpleks untuk menganalisa persamaan linier dalam menghitung keuntungan maksimum. Penelitian ini menghasilkan keuntungan maksimum dengan metode simpleks.

\subsection{Tinjauan Pustaka}

\subsubsection{Pemrograman Linier}

Pemrograman linier adalah suatu teknis perencanaan yang bersifat analitis yang analisisnya menggunakan model matematika, dengan tujuan menemukan beberapa alternatif pemecahan optimum terhadap persoalan. [1] Bentuk umum pemrograman linier sebagai berikut:

Fungsi Tujuan:

Maksimumkan atau minimumkan

$Z=c_{1} x_{1}+c_{2} x_{2}+\cdots+c_{n} x_{n}$
Kendala yang membatasi:

$a_{11} x_{1}+a_{12} x_{2}+\cdots+a_{1 n} x_{n}=/ \leq / \geq b_{1}$

$a_{21} x_{1}+a_{22} x_{2}+\cdots+a_{2 n} x_{n}=/ \leq / \geq b_{2}$

$a_{m 1} x_{1}+a_{m 2} x_{2}+\cdots+a_{m n} x_{n}=/ \leq / \geq b_{m}$

$x_{1}, x_{2}, \ldots, x_{n} \geq 0$

Simbol $x_{1}, x_{2}, \ldots, x_{n},\left(x_{i}\right)$ menunjukkan variabel keputusan. Jumlah variabel keputusan $\left(x_{i}\right)$ tergantung dari jumlah kegiatan atau aktivitas yang dilakukan untuk mencapai tujuan. Simbol $c_{1}, c_{2}, \ldots, c_{n}$ merupakan kontribusi tiap variabel keputusan terhadap tujuan, disebut juga koefisien fungsi tujuan pada model matematikanya. Simbol $a_{11}, \ldots, a_{1 n}, \ldots, a_{m n}$ merupakan penggunaan per unit variabel keputusan akan kendala yang membatasi, atau disebut juga sebagai koefisien fungsi kendala pada model matematikanya. Simbol $b_{1}, b_{2}, \ldots, b_{m}$ menunjukkan jumlah tiap kendala yang ada. Jumlah fungsi kendala akantergantung dari banyaknya kendala yang terbatas. [8]

\subsubsection{Metode Simpleks}

Metode simpleks didefinisikan sebagai cara penyelesaian program linier yang memiliki variabel keputusan minimal dua dengan alat bantu tabel. Metode simpleks memecahkan persoalan pemrograman linier dengan jalan memperoleh suatu pemecahan fisibel dengan suatu prosedur iteratif menyempurnakan pemecahan sampai diperoleh suatu pemecahan optimal. $[3,5,7,9,10]$

Langkah-langkah penyelesaian metode simpleks adalah sebagai berikut:[12]

a. Mengubah fungsi tujuan dengan batasan, setelah semua fungsi tujuan diubah maka fungsi tujuan diubah menjadi fungsi implisit.

b. Menyusun persamaan-persamaan ke dalam tabel simpleks.

c. Memilih kolom kunci

Dengan memilih kolom yang mempunyai nilai

pada garis fungsi tujuan yang bernilai negatif

dengan angka terbesar

d. Memilih baris kunci

Pilih baris yang mempunyai limit rasio dengan

angka terkecil.

Limit rasio $=$ nilai kanan / nilai kolom kunci

e. Mengubah nilai baris kunci

Nilai baris kunci diubah dengan cara membagi pada

dengan angka kunci, ganti variabel dasar

baris kunci dengan variabel yang terdapat di bagian atas kolom kunci.

f. Mengubah nilai-nilai selain pada baris kunci Untuk mengubahnya menggunakan rumus 
Baris baru $=$ baris lama - (koefisien per kolom kunci * nilai baris kunci).

g. Lanjutkan perbaikan atau perubahan ulangi fungsi

langkah c - f, sampai semua nilai pada

tujuan berharga positif

\subsubsection{Analisis Sensitivitas}

Analisis sensitivitas adalah suatu analisis untuk mengetahui kelayakan tingkat optimal terhadap kemungkinan perubahan setiap variabel yang dilibatkan dalam fungsi. $[6,11]$

Definisi:

Andaikan $B V_{i}$ adalah variabel dasar untuk baris ke- $i$ tabel optimal, dapat didefinisikan $B V=$ $B V_{1}, B V_{2}, \ldots, B V_{m}$ adalah himpunan variabel dasar dalam tabel optimal $[6,11]$

Didefinisikan vektor $x_{B V}=\left(\begin{array}{c}x_{B V 1} \\ x_{B V 2} \\ \vdots \\ x_{B V m}\end{array}\right)$

$N B V=$ himpunan variabel bukan dasar dalam tabel optimal.

Bentuk umum model pemrograman linier dapat dinyatakan dalam Maksimumkan atau minimumkan

$Z=c_{B V} x_{B V}+c_{N B V} x_{N B V}$

$B x_{B V}+N x_{N B V}=b$

$x_{B V}, x_{N B V} \geq 0$

Keterangan :

$\mathrm{Z}$ = fungsi objektif atau fungsi tujuan.

$c_{B V}=$ keofisien fungsi tujuan untuk variabelvariabel dasar.

$x_{B V}=$ vektor dari variabel dasar.

$x_{N B V}=$ adalah vektor dari variabel bukan dasar.

$B=$ matriks dari koefisien kendala, khusus untuk variabel-variabel dasar.

$b=$ vektor pada sisi kanan kendala.

$N=$ matriks yang kolom-kolomnya adalah kolom variabel bukan dasar.

Rumus untuk menghitung tabel optimal dari permasalahan pemrograman linier awal, yaitu : Kolom $x_{j}$ dalam kendala tabel optimal $=B^{(-1)} a_{j}$

Sisi kanan kendala tabel optimal $=B^{(-1)} b$

Koefisien untuk baris 0 pada tabel optimal

$\hat{c}_{j}=\left(c_{B V} B^{(-1)}\right) a_{j}-c_{j}$

Koefisien variabel slack $S_{i}$ baris 0 optimal $=$

(elemen ke- $i$ dari $c_{B V} B^{(-1)}$ )

\section{METODE PENELITIAN}

\subsection{Pengumpulan Data}

Data yang digunakan adalah data yang diperoleh dari Badan Pusat Statistik (BPS) Kabupaten Cilacap tahun 2014-2016. Data yang dianalisis adalah data produksi dan luas budidaya ikan di air tawar (kolam) serta ikan di air payau (tambak). Luas budidaya ikan di air tawar (kolam) per tahun yaitu 497,84 Ha, 497,34 Ha, dan $366 \mathrm{Ha}$. Luas budidaya ikan di air payau (tambak) per tahun yaitu 1420,97 Ha, 1420,94 Ha dan $932 \mathrm{Ha}$. Keseluruhan luas budidaya selama 3 tahun untuk jenis ikan di air tawar (kolam) yaitu 1361,18 Ha dan untuk jenis ikan di air payau (tambak) yaitu 3773,91 Ha. Produksi budidaya ikan di air tawar (kolam) per tahun yaitu $4.443 .962 \mathrm{~kg}, \quad 5.750 .795 \mathrm{~kg}$, dan $5.982 .394 \mathrm{~kg}$. Produksi budidaya ikan di air payau (tambak) per tahun yaitu $1.903 .087 \mathrm{~kg}, 1.596 .613$ $\mathrm{kg}$, dan $1.613 .999 \mathrm{~kg}$. Keseluruhan produksi budidaya selama 3 tahun untuk jenis ikan di air tawar (kolam) yaitu 16.177.151 kg dan untuk jenis ikan di air payau (tambak) yaitu $5.113 .699 \mathrm{~kg}$.

\subsection{Membentuk Model Matematika}

Memodelkan fungsi tujuan dan fungsi kendala. Fungsi tujuan disusun untuk ikan di air tawar (kolam) dan ikan di air payau (tambak), sehingga ada dua fungsi tujuan. Selanjutnya dibuat fungsi bersama.

\subsection{Penyelesaian Model Matematika}

Menyelesaikan pemaksimal produksi ikan di air tawar (kolam) dan ikan di air payau (tambak) menggunakan metode simpleks. Solusi optimal yang diperoleh dari metode simpleks diuji kelayakan perubahannya secara analisis sensitivitas.

\subsection{Menganalisis Hasil}

\subsection{Membuat Kesimpulan}

\section{PEMBAHASAN}

\subsection{Pembentukan Model Pemrograman Linier}

Produksi total merupakan jumlah dari produksi ikan di air tawar (kolam) dan ikan di air payau (tambak). Berdasarkan bentuk umum persoalan pemrograman linier, maka bentuk model pemrograman linier secara khusus untuk produksi ikan air tawar (kolam) dan ikan air payau (tambak) di Kabupaten Cilacap selama 3 tahun sebagai berikut

Fungsi tujuan :

Memaksimumkan

$Z=$

$8,926486 x_{1}+11,5631057 x_{2}+$

$16,3453388 x_{3}+1,3392872 \mathrm{y}_{1}+$

$1,1236315 \mathrm{y}_{2}+1,7317586 \mathrm{y}_{3}$

Adapun variabel yang digunakan adalah sebagai berikut :

$x_{i}=$ luas untuk jenis ikan di air tawar (kolam) tahun ke- $i$.

$y_{i}=$ luas untuk jenis ikan di air payau (tambak) tahun ke-i.

$i=1,2,3$ menyatakan tahun penelitian, Tahun penelitian ke-1 = tahun 2014, Tahun penelitian ke-2 = tahun 2015, Tahun penelitian ke-3 = tahun 2016. 
$c_{j}=$ koefisien fungsi tujuan ke- $j$ yang menyatakan produktivitas masing-masing jenis ikan tiap tahun penelitian.

$$
j=1,2,3, \cdots, 6 \text {. }
$$

Pada permasalahan ini kendalanya adalah sebagai berikut :

a. Luas kolam tidak boleh lebih dari luas kolam maksimum

$x_{1}+x_{2}+x_{3} \leq 1361,18$

b. Luas tambak tidak boleh lebih dari luas tambak maksimum

$$
\mathrm{y}_{1}+\mathrm{y}_{2}+\mathrm{y}_{3} \leq 3773,91
$$

c. $x_{1}, x_{2}, x_{3}, \mathrm{y}_{1}, \mathrm{y}_{2}, \mathrm{y}_{3} \geq 0$

Persamaan (14) fungsi tujuan model pemrograman linier diubah ke bentuk kanonik :

$Z-8,926486 x_{1}-11,5631057 x_{2}$

$-16,3453388 x_{3}-1,3392872 y_{1}$ $-\quad 1,1236315 y_{2}-1,7317586 y_{3}=0$

Dengan kendala:

$x_{1}+x_{2}+x_{3}+S_{1}=1361,18$

$\mathrm{y}_{1}+\mathrm{y}_{2}+\mathrm{y}_{3}+S_{2}=3773,91$

$x_{1}, x_{2}, x_{3}, \mathrm{y}_{1}, \mathrm{y}_{2}, \mathrm{y}_{3}, S_{1}, S_{2} \geq 0$

3.2 Perhitungan Persoalan Pemrograman Linier Menggunakan Metode Simpleks

Model pemrograman linier pada Persamaan 18, kemudian disusun ke dalam tabel simpleks. Iterasi awal metode Simpleks disajikan Tabel 1. Pada Tabel 2 dan Tabel 3 menunjukan iterasi ke satu dan dua. Tabel simpleks terakhir (tabel optimal) ditunjukan dalam Tabel 4. Iterasi berhenti dan tabel dinyatakan optimum karena nilai $C_{j}-Z_{j} \leq 0$.

\begin{tabular}{|c|c|c|c|c|c|c|c|c|c|c|}
\hline \multirow{2}{*}{$C_{j}$} & \multirow{2}{*}{$\begin{array}{c}\text { Basis } \\
\text { Variabel }\end{array}$} & $x_{1}$ & $x_{2}$ & $x_{3}$ & $y_{1}$ & $y_{2}$ & $y_{3}$ & $S_{1}$ & $S_{2}$ & \multirow{2}{*}{$\begin{array}{c}\text { Right } \\
\text { hand side }\end{array}$} \\
\hline & & 8,926486 & 11,5631057 & 16,3453388 & 1,3392872 & 1,1236315 & 1,7317586 & 0 & 0 & \\
\hline 0 & $S_{1}$ & 1 & 1 & 1 & 0 & 0 & 0 & 1 & 0 & 1361,18 \\
\hline 0 & $S_{2}$ & 0 & 0 & 0 & 1 & 1 & 1 & 0 & 1 & 3773,91 \\
\hline & $Z_{j}$ & & & & & & & & & \\
\hline & $C_{j}-Z_{j}$ & & & & & & & & & \\
\hline
\end{tabular}

Tabel 1. Iterasi Awal Metode Simpleks

\begin{tabular}{|c|c|c|c|c|c|c|c|c|c|c|}
\hline$C_{j}$ & Basis & $x_{1}$ & $x_{2}$ & $x_{3}$ & $y_{1}$ & $y_{2}$ & $y_{3}$ & $S_{1}$ & $S_{2}$ & \multirow{2}{*}{$\begin{array}{c}\text { Right } \\
\text { hand side }\end{array}$} \\
\hline${ }^{j}$ & Variabel & 8,926486 & 11,5631057 & 16,3453388 & 1,3392872 & 1,1236315 & 1,7317586 & 0 & 0 & \\
\hline 0 & $S_{1}$ & 1 & 1 & 1 & 0 & 0 & 0 & 1 & 0 & 1361,18 \\
\hline 0 & $S_{2}$ & 0 & 0 & 0 & 1 & 1 & 1 & 0 & 1 & 3773,91 \\
\hline & $Z_{j}$ & 0 & 0 & 0 & 0 & 0 & 0 & 0 & 0 & 0 \\
\hline & $C_{j}-Z_{j}$ & 8,926486 & 11,5631057 & 16,3453388 & 1,3392872 & 1,1236315 & 1,7317586 & 0 & 0 & \\
\hline
\end{tabular}

Tabel 2. Iterasi 1 Metode Simpleks

\begin{tabular}{|c|c|c|c|c|c|c|c|c|c|c|}
\hline \multirow{2}{*}{$C_{j}$} & \multirow{2}{*}{$\begin{array}{c}\text { Basis } \\
\text { Variabel }\end{array}$} & $x_{1}$ & $x_{2}$ & $x_{3}$ & $y_{1}$ & $y_{2}$ & $y_{3}$ & $S_{1}$ & $S_{2}$ & \multirow{2}{*}{$\begin{array}{l}\text { Right hand } \\
\text { side }\end{array}$} \\
\hline & & 8,926486 & 11,5631057 & 16,3453388 & 1,3392872 & 1,1236315 & 1,7317586 & 0 & 0 & \\
\hline 16,3453388 & $x_{3}$ & 1 & 1 & 1 & 0 & 0 & 0 & 1 & 0 & 1361,18 \\
\hline \multirow[t]{3}{*}{0} & $S_{2}$ & 0 & 0 & 0 & 1 & 1 & 1 & 0 & 1 & 3773,91 \\
\hline & $Z_{j}$ & 16,3453388 & 16,3453388 & 16,3453388 & 0 & 0 & 0 & 16,3453388 & 0 & 22248,9483 \\
\hline & $C_{j}-Z_{j}$ & $-7,4188528$ & $-4,7822331$ & 0 & 1,3392872 & 1,1236315 & 1,7317586 & $-16,3453388$ & 0 & \\
\hline
\end{tabular}

Tabel 3. Iterasi 2 Metode Simpleks

\begin{tabular}{|c|c|c|c|c|c|c|c|c|c|c|}
\hline$C_{j}$ & $\begin{array}{c}\text { Basis } \\
\text { Varial }\end{array}$ & $x_{1}$ & $x_{2}$ & $x_{3}$ & $y_{1}$ & $y_{2}$ & $y_{3}$ & $S_{1}$ & $S_{2}$ & \multirow{2}{*}{$\begin{array}{c}\text { Right hand } \\
\text { side }\end{array}$} \\
\hline & & 8,926486 & 11,5631057 & 16,3453388 & 1,3392872 & 1,1236315 & 1,7317586 & 0 & 0 & \\
\hline 16,3453388 & $x_{3}$ & 1 & 1 & 1 & 0 & 0 & 0 & 1 & 0 & 1361,18 \\
\hline 1,7317586 & $y_{3}$ & 0 & 0 & 0 & 1 & 1 & 1 & 0 & 1 & 3773,91 \\
\hline & $Z_{j}$ & 16,3453388 & 16,3453388 & 16,3453388 & 1,7317586 & 1,7317586 & 1,7317586 & 16,3453388 & 1,7317586 & 28784,4494 \\
\hline & $C_{j}-Z_{j}$ & $-7,4188528$ & $-4,7822331$ & 0 & $-0,3924714$ & $-0,6081271$ & 0 & $-16,3453388$ & $-1,7317586$ & \\
\hline
\end{tabular}

Tabel 4. Iterasi 3 (Iterasi Optimum) Metode Simpleks

\subsection{Analisis Perubahan Solusi secara Sensitivitas}

Perubahan yang mungkin terjadi pada masalah pemrograman linier produksi ikan di Kabupaten Cilacap adalah :
1. Perubahan produktivitas kolam dan tambak Dapat terjadi jika diterapkan teknologi yang baru sehingga produktivitas dapat naik atau dapat turun jika terjadi kegagalan. 
2. Perubahan luas kolam dan tambak

Dapat terjadi jika ada penambahan atau pengurangan luas kolam dan tambak.

3.3.1 Pengujian Perubahan Produktivitas Kolam dan Tambak (Koefisien Fungsi Tujuan)

Perubahan untuk koefisien fungsi tujuan digolongkan dalam dua jenis, yaitu :

1. Perubahan koefisien fungsi tujuan untuk variabel dasar $\left(c_{B V}\right)$

2. Perubahan koefisien fungsi tujuan untuk variabel bukan dasar $\left(c_{N B V}\right)$.

Dari Tabel 4 dapat didefinisikan $x_{B V}$ dan $x_{B N V}$ yaitu:

$x_{B V}=\left(\begin{array}{l}x_{3} \\ y_{3}\end{array}\right)$ dan $\quad x_{N B V}=\left(\begin{array}{l}x_{1} \\ x_{2} \\ y_{1} \\ y_{2} \\ S_{1} \\ S_{2}\end{array}\right)$

dengan :

$B V=$ himpunan variabel dasar dalam tabel optimal.

$N B V=$ himpunan variabel bukan dasar dalam tabel optimal.

$x_{B V}=$ vektor dari variabel dasar.

$x_{N B V}=$ vektor dari variabel bukan dasar.

$c_{B V}=$ koefisien fungsi tujuan untuk variabelvariabel dasar.

$c_{N B V}=$ koefisien fungsi tujuan untuk variabelvariabel bukan dasar.

Dari persamaan (18) diperoleh

$c_{B V}=(16,34533881,7317586)$

$c_{N B V}$

$=\left(\begin{array}{llll}8,926486 & 11,5631057 & 1,3392872 & 1,1236315\end{array}\right.$

$a_{1}=\left(\begin{array}{l}1 \\ 0\end{array}\right), a_{2}=\left(\begin{array}{l}1 \\ 0\end{array}\right), a_{3}=\left(\begin{array}{l}0 \\ 1\end{array}\right)$,

$a_{4}=\left(\begin{array}{l}0 \\ 1\end{array}\right), a_{5}=\left(\begin{array}{l}1 \\ 0\end{array}\right), a_{6}=\left(\begin{array}{l}0 \\ 1\end{array}\right)$

\subsubsection{Perubahan Koefisien Fungsi Tujuan Untuk Variabel Bukan Dasar}

Perubahan koefisien fungsi tujuan untuk variabel bukan dasar dapat terjadi pada $c_{N B V}$ yaitu koefisien $x_{1}, x_{2}, y_{1}, y_{2}, S_{1}, S_{2}$.

Diketahui matriks dari koefisien kendala untuk variabel dasar, yaitu

$B=\left(\begin{array}{ll}1 & 0 \\ 0 & 1\end{array}\right), B^{-1}=B$

Kemudian dihitung

$C_{B V} B^{-1}=(16,34533881,7317586)\left(\begin{array}{ll}1 & 0 \\ 0 & 1\end{array}\right)$

$=(16,3453388$ 1,7317586$)$

a. Perubahan Koefisien Fungsi Tujuan untuk $x_{1}\left(c_{1}\right)$

Besarnya perubahan dinyatakan dengan $\Delta$ dan $c_{1}$ berubah dari 8,926486 menjadi $(8,926486+$ $\Delta)$.

Berdasarkan persamaan (12), diperoleh :

$$
\begin{array}{r}
\hat{c}_{1}=(16,3453388 \quad 1,7317586)\left(\begin{array}{l}
1 \\
0
\end{array}\right) \\
=(8,926486+\Delta) \\
=(7.4188528-\Delta)
\end{array}
$$

Variabel dasar tetap optimal jika $\hat{c}_{1} \geq 0$. Sehingga $\Delta \leq 7.4188528$. Artinya jika nilai $c_{1}$ naik sebesar 7.4188528 atau kurang, maka variabel dasar tetap optimal, tetapi jika $c_{1}$ naik lebih besar dari 7.4188528, maka variabel dasar tidak lagi optimal.

b. Perubahan Koefisien Fungsi Tujuan untuk $x_{2}\left(c_{2}\right)$

Besarnya perubahan dinyatakan dengan $\Delta$ dan $c_{2}$ berubah dari 11,5631057 menjadi $(11,5631057+\Delta)$.

Berdasarkan persamaan (12), diperoleh :

$$
\begin{array}{r}
\hat{c}_{2}=\left(\begin{array}{rr}
16,3453388 & 1,7317586
\end{array}\right)\left(\begin{array}{l}
1 \\
0
\end{array}\right) \\
-(11,5631057+\Delta) \\
=(4,7822331-\Delta)
\end{array}
$$

Variabel dasar tetap optimal jika $\hat{c}_{2} \geq 0$. Sehingga $\Delta \leq 4,7822331$. Artinya jika nilai $c_{2}$ naik sebesar 4,7822331 atau kurang, maka variabel dasar tetap optimal, tetapi jika $c_{2}$ naik lebih besar dari 4,7822331, maka variabel dasar tidak lagi optimal.

\section{c. Perubahan koefisien Fungsi Tujuan untuk} $y_{1}\left(c_{3}\right)$

Besarnya perubahan dinyatakan dengan $\Delta$ dan $c_{3}$ berubah dari 1,3392872 menjadi $(1,3392872+$ $\Delta)$.

Berdasarkan persamaan (12), diperoleh :

$$
\begin{gathered}
\hat{c}_{3}=(16,3453388 \quad 1,7317586)\left(\begin{array}{l}
0 \\
1
\end{array}\right) \\
=(0,3924714-\Delta)
\end{gathered}
$$

Variabel dasar tetap optimal jika $\hat{c}_{3} \geq 0$. Sehingga $\Delta \leq 0,3924714$. Artinya jika nilai $c_{3}$ naik sebesar 0,3924714 atau kurang, maka variabel dasar tetap optimal, tetapi jika $c_{3}$ naik lebih besar dari 0,3924714, maka variabel dasar tidak lagi optimal.

\section{d. Perubahan koefisien Fungsi Tujuan untuk} $\boldsymbol{y}_{2}\left(c_{4}\right)$

Besarnya perubahan dinyatakan dengan $\Delta$ dan $c_{4}$ berubah dari 1,1236315 menjadi $(1,1236315+$ $\Delta)$.

Berdasarkan persamaan (12), diperoleh :

$$
\begin{aligned}
& \hat{c}_{4}=(16,3453388 \quad 1,7317586)\left(\begin{array}{l}
0 \\
1
\end{array}\right) \\
& =(0,6081271-\Delta)
\end{aligned}
$$

Variabel dasar tetap optimal jika $\hat{c}_{4} \geq 0$. Sehingga $\Delta \leq 0,6081271$. Artinya jika nilai $c_{4}$ naik sebesar 0,6081271 atau kurang, maka variabel dasar tetap optimal, tetapi jika $c_{4}$ naik 
lebih besar dari 0,6081271, maka variabel dasar tidak lagi optimal.

\subsubsection{Perubahan Koefisien Fungsi Tujuan Untuk Variabel Dasar}

Perubahan koefisien fungsi tujuan untuk variabel dasar dapat terjadi pada $c_{B V}$ yaitu koefisien $x_{3}, y_{3}$. Jika $c_{B V}$ berubah, maka perlu dilihat pengaruhnya pada solusi optimal.

Pengujian kelayakan perubahan fungsi tujuan untuk $x_{3}$ dan $y_{3}$ :

\section{a. Perubahan Koefisien Fungsi Tujuan untuk $x_{3}\left(c_{5}\right)$ \\ Besarnya perubahan dinyatakan dengan $\Delta$ dan $c_{5}$ berubah dari 16,3453388 menjadi $(16,3453388+\Delta)$ \\ Dengan $c_{B V}$ baru,

$$
c_{B V}=((16,3453388+\Delta) \quad 1,7317586)
$$

Maka diperoleh,

$$
\begin{aligned}
& c_{B V} B^{-1} \\
& =\left(\begin{array}{ll}
16,3453388+\Delta & 1,7317586
\end{array}\right)\left(\begin{array}{ll}
1 & 0 \\
0 & 1
\end{array}\right) \\
& =(16,3453388+\Delta \quad 1,7317586)
\end{aligned}
$$

Koefisien setiap variabel bukan dasar $\left(c_{N B V}\right)$ dalam baris 0 tabel optimum yang baru yaitu :

$$
\begin{aligned}
& \hat{c}_{1}=(16,3453388+\Delta \quad 1,7317586)\left(\begin{array}{l}
1 \\
0
\end{array}\right) \\
& -(8,926486) \\
& =(7.4188528+\Delta) \\
& \hat{c}_{2}=(16,3453388+\Delta \quad 1,7317586)\left(\begin{array}{l}
1 \\
0
\end{array}\right) \\
& \text { - (11,5631057) } \\
& =(4,7822331+\Delta) \\
& \hat{c}_{3}=(16,3453388+\Delta \quad 1,7317586)\left(\begin{array}{l}
0 \\
1
\end{array}\right) \\
& -(1,3392872) \\
& =(0,3924714) \\
& \text { (36) } \\
& \hat{c}_{4}=(16,3453388+\Delta 1,7317586)\left(\begin{array}{l}
0 \\
1
\end{array}\right) \\
& \text { - }(1,1236315) \\
& =(0,6081271)
\end{aligned}
$$

Koefisien $S_{1}$ dalam baris 0 yaitu elemen ke 1 dari $c_{B V} B^{-1}=16,3453388+\Delta$

Koefisien $S_{2}$ dalam baris 0 yaitu elemen ke 2 dari $c_{B V} B^{-1}=1,7317586$

Dengan demikian baris 0 tabel optimum yang baru adalah:

$Z=(7.4188528+\Delta) x_{1}$

$+(4,7822331+\Delta) x_{2}$

$+(0,3924714) y_{1}$

$+(0,6081271) y_{2}$

$+(16,3453388+\Delta) S_{1}$

$+(1,7317586) S_{2}$

Memperhatikan baris 0 baru, variabel yang dasar bersangkutan tetap optimal jika dan hanya jika kondisi berikut dipenuhi:
$7.4188528+\Delta \geq 0$ atau

$\Delta \geq-7.4188528$

$4,7822331+\Delta \geq 0$ atau

$\Delta \geq-4,7822331$

$16,3453388+\Delta \geq 0$ atau

$\Delta \geq-16,3453388$

Hal ini berarti solusi basis tetap optimal pada nilai $\Delta \geq-4,7822331$.Jika nilai $c_{5}$ turun sebesar 4,7822331, maka solusi basis tetap optimal. Pada interval 11,5631057 $\leq c_{5} \leq$ 16,3453388 solusi basis pada interval ini tetap optimal.

b. Perubahan Koefisien Fungsi Tujuan untuk $y_{3}\left(c_{6}\right)$

Besarnya perubahan dinyatakan dengan $\Delta$ dan $c_{6}$ berubah dari 1,7317586 menjadi $(1,7317586+\Delta)$.

Dengan $c_{B V}$ baru,

$c_{B V}=(16,3453388 \quad(1,7317586+\Delta))$

Maka diperoleh,

$c_{B V} B^{-1}=$

$\left(\begin{array}{ll}16,3453388 & 1,7317586+\Delta\end{array}\right)\left(\begin{array}{ll}1 & 0 \\ 0 & 1\end{array}\right)=$

$(16,3453388 \quad 1,7317586+\Delta)$

Koefisien setiap variabel bukan dasar dalam baris 0 tabel optimum yang baru yaitu

$\hat{c}_{1}=\left(\begin{array}{ll}16,3453388 & 1,7317586+\Delta\end{array}\right)\left(\begin{array}{l}1 \\ 0\end{array}\right)-$

$(8,926486)=(7.4188528)(46)$

$\hat{c}_{2}=(16,3453388 \quad 1,7317586+\Delta)\left(\begin{array}{l}1 \\ 0\end{array}\right)-$

$(11,5631057)=(4,7822331)$

$\hat{c}_{3}=(16,3453388 \quad 1,7317586+\Delta)\left(\begin{array}{l}0 \\ 1\end{array}\right)$

$(1,3392872)=(0,3924714+\Delta)$

$\hat{c}_{4}=\left(\begin{array}{ll}16,3453388 & 1,7317586+\Delta\end{array}\right)\left(\begin{array}{l}0 \\ 1\end{array}\right)-$

$(1,1236315)=(0,6081271+\Delta)$

Koefisien $S_{1}$ dalam baris 0 yaitu elemen ke 1 dari $c_{B V} B^{-1}=16,3453388$

Koefisien $S_{2}$ dalam baris 0 yaitu elemen ke 2 dari $c_{B V} B^{-1}=1,7317586+\Delta$

Dengan demikian baris 0 tabel optimum yang baru adalah:

$Z=(7.4188528) x_{1}+(4,7822331) x_{2}$ $+(0,3924714+\Delta) y_{1}+(0,6081271+\Delta) y_{2}$ $+(16,3453388) S_{1}+(1,7317586+\Delta) S_{2}$

Memperhatikan baris 0 baru, variabel yang dasar bersangkutan tetap optimal jika dan hanya jika kondisi berikut dipenuhi:

$0,3924714+\Delta \geq 0$ atau

$\Delta \geq-0,3924714$

$0,6081271+\Delta \geq 0$ atau 
$\Delta \geq-0,6081271$

$1,7317586+\Delta \geq 0$ atau

$\Delta \geq-1,7317586$

Hal ini berarti solusi basis tetap optimal pada nilai $\Delta \geq-0,3924714$. Jika nilai $c_{6}$ turun sebesar 0,3924714, maka solusi basis tetap optimal. Pada interval 1,339287 $\leq c_{6} \leq$ 1,7317586 solusi basis pada interval ini tetap optimal.

\subsection{Pengujian Perubahan Luas Kolam Dan} Tambak (Sisi Kanan Kendala)

Sisi kanan dari kendala-kendala tersebut terbentuk : $b=\left(\begin{array}{l}1361,18 \\ 3773,91\end{array}\right)$

a. Perubahan sisi kanan pada kendala pertama $\left(b_{1}\right)$

Jika $b_{1}$ berubah dari 1361,18 menjadi $(1361,18+\Delta)$, maka sisi kanan kendala pada tabel optimal setelah perubahan adalah:

$$
\begin{aligned}
B^{-1} b & =\left(\begin{array}{ll}
1 & 0 \\
0 & 1
\end{array}\right)\left(\begin{array}{c}
1361,18+\Delta \\
3773,91
\end{array}\right) \\
& =\left(\begin{array}{c}
1361,18+\Delta \\
3773,91
\end{array}\right)
\end{aligned}
$$

Solusi basis tetap optimal jika $\Delta \geq$ $-1361,18$. Solusi basis tetap optimaljika sisi kanan kendala pertama berubah pada interval $0-1361,18$.

b. Perubahan sisi kanan pada kendala ke dua $\left(b_{2}\right)$
Jika $b_{2}$ berubah dari 3773,91 menjadi $(3773,91+\Delta)$, maka sisi kanan kendala pada tabel optimal setelah perubahan adalah:

$$
\begin{aligned}
B^{-1} b & =\left(\begin{array}{ll}
1 & 0 \\
0 & 1
\end{array}\right)\left(\begin{array}{c}
1361,18 \\
3773,91+\Delta
\end{array}\right) \\
& =\left(\begin{array}{c}
1361,18 \\
3773,91+\Delta
\end{array}\right)
\end{aligned}
$$

Solusi basis tetap optimal jika $\Delta \geq$ $-3773,91$. Solusi basis tetap optimal jika sisi kanan kendala kedua berubah pada interval $0-3773,91$.

\section{KESIMPULAN}

Model pemrograman linier untuk optimasi produksi ikan air tawar (kolam) dan ikan air payau (tambak) di Kabupaten Cilacap adalah: Memaksimumkan

$$
\begin{aligned}
& Z=8,926486 x_{1}+11,5631057 x_{2} \\
& +\quad 16,3453388 x_{3}+1,3392872 y_{1} \\
& +\quad 1,1236315 y_{2}+1,7317586 y_{3}
\end{aligned}
$$$$
\text { dengan kendala }
$$

$$
\begin{aligned}
& x_{1}+x_{2}+x_{3} \leq 1361,18 \\
& \mathrm{y}_{1}+\mathrm{y}_{2}+\mathrm{y}_{3} \leq 3773,91 \\
& x_{1}, x_{2}, x_{3}, \mathrm{y}_{1}, \mathrm{y}_{2}, \mathrm{y}_{3} \geq 0
\end{aligned}
$$

Produktivitas maksimum ikan air tawar

\begin{tabular}{|c|c|c|c|c|}
\hline Jenis Ikan & Kriteria & 2014 & 2015 & 2016 \\
\hline \multirow[t]{2}{*}{$\begin{array}{l}\text { Ikan Air } \\
\text { Tawar } \\
\text { (Kolam) }\end{array}$} & $\begin{array}{l}\text { Produktivitas } \\
\text { (Ton/Ha) }\end{array}$ & $\begin{array}{c}8,926486 \\
- \\
16,3453388\end{array}$ & $\begin{array}{c}11,5631057 \\
- \\
16,3453388\end{array}$ & $\begin{array}{c}11,5631057 \\
- \\
163453388\end{array}$ \\
\hline & $\begin{array}{l}\text { Luas Kolam } \\
\text { (Ha) }\end{array}$ & \multicolumn{3}{|c|}{$0-1361,18$} \\
\hline \multirow[t]{2}{*}{$\begin{array}{l}\text { Ikan Air } \\
\text { Payau } \\
\text { (Tambak) }\end{array}$} & $\begin{array}{l}\text { Produktivitas } \\
\text { (Ton/Ha) }\end{array}$ & $\begin{array}{c}1,3392872 \\
- \\
1,7317586\end{array}$ & $\begin{array}{r}1,12 \\
-\quad \\
1,7317586\end{array}$ & $\begin{array}{c}1,33928 \\
- \\
1,7317586\end{array}$ \\
\hline & $\begin{array}{l}\text { Luas Tambak } \\
\text { (Ha) }\end{array}$ & \multicolumn{3}{|c|}{$0-3773,91$} \\
\hline
\end{tabular}
(kolam) dan ikan air payau (tambak) selama tahun 2014 - 2016 diperoleh sebanyak $28.784,4494$ ton, meningkat dari hasil produksi sebelum dioptimasi sebesar 21.290,850 ton.

Berdasarkan hasil analisis sensitivitas, solusi basis untuk persoalan pemrograman linier ini tetap optimal dan fisibel jika kondisi seperti dalam Tabel 5 berikut dipenuhi:

Tabel 5. Hasil Analisis Sensitivitas

\section{DAFTAR PUSTAKA}

[1] Aminuddin. 2005. Prinsip-prinsip Riset Operasi. Jakarta: Erlangga.

[2] Badan Pusat Statistik Kabupaten Cilacap. 2018. Cilacap Dalam Angka Tahun 2018. Cilacap: Kantor Statistik Kabupaten Cilacap

[3] Bazaran, M.S. dkk. 2006. Nonlinier Programming: Theory and Algorithms. Third Edition. New Jersey: John Willey and Sons, Inc.
[4] Elva, YA. 2015. Penerapan Metode Hongaria dan Metode Simpleks dalam Upaya Optimasi. Universitas Islam Negeri Maulana Malik Ibrahim. Malang: Jurusan Matematika.

[5] Fitzsimmons J.A. and Sullivan R.S. 1982. Service Operations Management. New York: McGraw-Hill, Inc.

[6] Indrawati, Octarina, S dan Suandi, N. 2012. Aplikasi Metode Simpleks pada Produksi Padi Di Kabupaten Ogan Ilir serta Analisis Kelayakan Produksi Secara Sensitivitas. Jurnal Penelitian Sains MIPA UNSRI. 
Sumatera Selatan : Jurusan Matematika UNSRI.

[7] Kakiay. 2010. Dasar Teori Antrian untuk Kehidupan Nyata. Yogyakarta : Andi.

[8] Siringoringo, H. 2005. Pemrograman Linier: Seri Teknik Riset Operasional. Yogyakarta: Graha Ilmu.

[9] Sundaram, R. K.1996. A First Course in Optimization Theory. Cambridge :University Press.

[10] Suprapto. 2006. Matematika untuk Ekonomi dan Bisnis Edisi Kedua. Bogor : Ghalia Indonesia
[11]Winston, L.W. 1987. Operation Research: Applications and Algorithms. Boston: PWSKent Publishing Company.

[12] Zuhria N, Hery S, Ikwan L, dan Lince TS. 2016. Penerapan Metode Simpleks untuk Menganalisa Persamaan Linier dalam Menghitung Keuntungan Maksimum. Jurnal Riset Komputer (JURIKOM) STMIK Budi Darma: Medan. Vol. 3 No. 4, Agustus 2016 ISSN 2407-389X Hal : 42-48. 